\title{
Issues of decentralisation and central control in educational management:
}

The enabling and shaping role of technology

\author{
Arthur Tatnall and Allan Pitman \\ School of Information Systems, Victoria University, Australia and Faculty of Education, \\ University of Western Ontario, Canada
}

\begin{abstract}
School systems in many countries appear to have undergone a process of decentralisation in their administrative functions. Closer inspection, however, reveals that this has been linked with a tightening of central control in some areas. This paper will examine the role, in this process, played by the use of information technology in education management. It will use a discussion of how school systems in Victoria, Australia and Ontario, Canada have handled both decentralisation and the introduction of school management information systems to suggest that this introduction has led to a tighter coupling between schools and central education authorities, and within schools themselves.
\end{abstract}

Key words: information technology, educational management, centralisation

\section{INTRODUCTION}

For some years now the prevailing rhetoric on educational management around the world has been towards policies of decentralisation (Botterey, 1999; Gershberg, 1999; Sayed, 1999; Berkhout and Wielemans, 1999; Chapman, 2000). Advocates of educational decentralisation have argued that moving decision-making closer to the school and its local community will lead to greater community participation in education and better financial support for schools, and that this will make schools more responsive to local needs and conditions (Chapman, 2000). Another argument has been along the lines that decentralisation will enable market forces to deliver more effective education, and with greater efficiency (Berkhout and Wielemans,

The original version of this chapter was revised: The copyright line was incorrect. This has been corrected. The Erratum to this chapter is available at DOI: 10.1007/978-0-387-35615-0_52 
1999). Despite all this, however, it is apparent that decentralisation is rarely total, with some functions, such as curriculum and testing, almost always remaining under some degree of central control (Chapman, 2000).

This paper will not question the supposed advantages of decentralisation, but rather investigate how forms of central control can still be maintained in decentralised systems. In particular we will explore the role of information technology in supporting this central control. We will argue that the role of information technology is pivotal, and that without the various types of management information systems that exist in most schools, central control could not easily be maintained in larger school systems.

\section{THE MANAGEMENT OF SCHOOLS IN TWO DIFFERENT EDUCATION SYSTEMS}

Public schooling is commonly seen as the responsibility of the state, generally at either the national or provincial/state level. As such, it is subject to the pressures for control over its operations common to organisations funded from the public purse. In the case of schooling, this urge for control is manifested in two distinct areas: first, the system - its structures and personnel, and second, the curriculum - the work content of the schools.

In the two systems referred to in this paper, there are apparent similarities and equally important contrasts. In both Victoria, Australia and Ontario, Canada schooling is the responsibility of the state/province. Both systems have a central bureaucracy, with regional centres: in Victoria, Regional Offices of the Ministry of Education, and in Ontario, District School Boards. At the individual school level, both systems have school councils consisting of members of the community, teachers and school administration. These organisational similarities, however, mask deep differences in the ways in which power is distributed as the following discussion makes evident.

\subsection{Victoria, Australia}

The Commonwealth of Australia is a federation of six states and two territories, each of which has almost complete control of its own education system. In the 1980s, along with most other Australian states, Victoria began to decentralise the administration of its school system. The intention was to devolve much of the administration, formerly done centrally, to schools. Also during the 1980s, in an apparently contradictory trend, the Ministry of Education in Victoria began to re-centralise the control over school curriculum that it had largely relinquished in the 1970s. 
In parallel with devolution of administrative control the Education Ministry commenced building its own computer-based administrative system and distributing this to schools. An important aim of this computerisation project was to improve the financial accountability of schools to the Victorian government (Birse, 1994), and in its first implementation it consisted primarily of a standardised school accounting system. Soon the system was extended to cover all elements of school administration and reporting both to parents and back to the Ministry of Education.

Today, each Victorian school is managed by a school council consisting of the school principal, elected teachers, parents and community representatives. The school council or its executive (the school principal) controls most school administrative functions under the overall direction of the Victorian Department of School Education (DSE). Although some administrative functions are co-ordinated at a regional level, the only significant controlling body in school management is the DSE.

Curriculum remains under the central control of the DSE for years $\mathrm{K}-10$, and through the Victorian Board of Studies for years 11 and 12. The DSE administers a series of standardised tests of all students at several points during their schooling. While schools have some flexibility in interpreting the curriculum, the basic structure and content is determined and standards are set centrally.

In summary then, school councils manage each individual school with the school principal (as school council executive) exercising day-to-day control of all administrative functions. Regional education offices oversee some administrative functions and act to assist individual school principals where necessary. The DSE retains overall administrative control, and schools send back regular reports on their finances and other administrative activities. The DSE also retains control over the school curriculum.

\subsection{Ontario, Canada}

Canada is a confederation of nine provinces and three territories, each of which has constitutional control over its education system. The school system in Ontario is one in which, traditionally, a good deal of authority has rested at the local level. Following the Hall-Dennis Report (Provincial Committee on Aims and Objectives of Education in the Schools of Ontario, 1968), curricular decision-making was also devolved to the local school board level, continuing a trend which saw weaker and weaker specification of curriculum content from the centre. This period saw the abolition of the provincial examination system: individual schools award graduating grades to students in a context in which the content of the final two years of schooling have maintained fairly explicit content requirements in each 
subject. This took place in conjunction with an apparently countervailing trend of consolidation of local boards. The 1990s has seen a determined effort by government to re-grasp control over the curriculum and organisational structures of the province's school system.

The province now has a mandated curriculum in place: The Ontario Curriculum, which specifies subjects, their content by grade, and expected levels of achievement by students at each grade level. This is augmented by a series of provincial tests administered by the quasi-independent Education Quality Assessment Office (EQAO) in literacy and numeracy. These tests are specifically constructed to reflect and sample the outcomes specified in The Ontario Curriculum. A system for re-certification of teachers on a five year cycle is being implemented through a newly established Ontario College of Teachers, created by the government through Act of Parliament. The data storage and communication implications of these moves draw attention to the centrality of information systems in the efficacy of their implementation and subsequent operation.

A general observation can be made with respect to the heavy use of web sites and e-mail. Both the boards and the various central authorities (Ministry, College of Teachers and EQAO) make heavy use of e-mail for the transmission of memoranda, advertisements and the like of their web sites for providing access to policy documents and administrative forms, and the combination of the two for providing linkages between personnel at different locations and levels of central organisation. Within the system, at the Ministry and board levels, specific information systems packages are employed as management tools.

In summary, school boards manage much of the operations of schools, with principals acting as their agents and exercising day-to-day control. School councils are weak, with principals having primary reporting responsibilities to the board and, for some aspects, the Ministry directly.

\section{THE ROLE PLAYED BY INFORMATION TECHNOLOGY AND OTHER ACTORS}

In both Victoria and Ontario, several important actors are seen to emerge in determining the direction taken by the decentralisation of school management, and reassertion of central control over curriculum. Firstly there is the centrally-based Education Department (or Ministry). Next, at the local level, is the school principal (and her management team) along with the classroom teachers. Thirdly in Ontario the school boards, and in Victoria individual school councils, also play their parts. Another important actor, however, is the technology itself: the school management information 
system (SMIS). If we consider an actor to be an entity that actively contributes to the path taken by some particular undertaking, then all of these entities, including the SMIS, must be considered as actors.

When dealing with the related contributions of both human and nonhuman actors, actor-network theory (ANT) provides a useful framework. ANT offers a socio-technical approach in which neither social nor technical positions are privileged, by denying that purely social or purely technical relations are possible, and by asserting the world to be full of hybrid entities containing both human and non-human elements (Latour, 1993; 1996).

In an ANT framework, actors are seen to jostle, contest and negotiate with each other in an attempt to influence the final outcome in a direction to their own liking. The central Education Department, for example, might want to ensure that the SMIS is used to maximum effect to facilitate schools reporting back to itself. School principals, on the other hand, may be keen to do things their own way to as great an extent as possible, and seek to use the system to this end. Both actors attempt to use the SMIS to meet their own ends, while the software itself acts in the way it was designed (both intentionally and unintentionally) to act.

Each of the actors sees the problem of how best to manage a school, as part of an education system, in a somewhat different way, and each acts in an attempt to negotiate a solution that incorporates as much as possible of their view of the problem. Where the actions of the SMIS become important is in how they influence the way the problem is solved.

The way that the SMIS acts is principally through the way that schools, and the Education Department, need to make use of it. If the software has been written in such a way that the SMIS requires that certain financial and student data must be collected, but does not require the collection of certain other data, then this is what is likely to happen at the school level. Through its design, the SMIS has thus convinced schools to collect certain data and, although there is nothing to prevent the school still doing so, not to collect other data. The SMIS has thus acted to influence the way in which the school operates. This process of negotiation is not entirely in one direction as most information systems allow a certain degree of flexibility. Choices made by individual school principals to use this option rather than that, and to enter their data in a particular way when this is not specified by the system, can be seen as the schools negotiating with the SMIS.

The use of an SMIS, and the resulting additional interactions between all the actors, has resulted in a lengthening of the actor-networks in administration and in curriculum, both within and between schools. These lengthened networks can also be seen in terms of a tightening of the degree of coupling that exists within and between schools. 


\section{DECENTRALISATION AND COUPLING}

Some years ago Weick $(1976 ; 1982)$ proposed a theory of organisations in which he argued that schools are joined more loosely than other organisations, and that this has a fundamental influence on the way in which they operate. Weick introduced the concept of coupling in education systems and argued that schools function best if allowed to operate as loosely coupled systems.

For our purposes, the power of Weick's analysis lies in the capacity it provides to deal with apparently contradictory trends as they play out in the centralisation/decentralisation process. By paying attention to two distinct dimensions of coupling, we can tease out the ways in which the locations at the periphery of the organisation (schools) are linked to more central locations with respect to control of the nature of the work of schools (curriculum) and the administration of the system. It will be seen that by so doing, we can reconcile the ways in which these systems are seen to be both centralising and, to a greater or lesser degree, decentralising at the same time.

Our categorisation differs from that of Glassman (1973), who categorised the degree of coupling between two systems in terms of the activity of variables involving the technical core (technology, tasks, roles, territory and personnel) and office coupling mechanisms (positions, offices, responsibilities, opportunities, rewards and sanctions) they share. We are treating his pair of categories as subsets of the administrative dimension. Events are more responsive in tightly coupled systems but loosely coupled systems allow more professional individualism.

In both education systems, teachers must now write their student reports in a standard format using the SMIS. This contrasts with the situation prior to the introduction of these systems where individual schools, and even individual teachers could, to a large extent, determine the layout and structure of student reports. Principals are now able to expect that their teachers will all produce their student reports in a similar format, and in electronic form, representing a tightening of the coupling within a school between teachers and the principal.

We will contend that an important result of the use of school management information systems is their tendency to tighten the coupling within schools between the teachers and the principal. The introduction of the SMIS has also tightened the coupling between schools and central education authorities (Department or Ministry) by coercing schools into performing many of their administrative functions in a standard way determined by the software. 


\section{MIS AND THE TWO SYSTEMS}

School systems in both Victoria and Ontario are largely decentralised, but have important centralised aspects. Each school system also makes considerable use of school management information systems, and we want to pose a link between the two. Along with Telem (1998), we have argued that the use of the school MIS can be linked to the tightening of the coupling between schools and the Education Department, and also between teachers and principals.

While not taking a deterministic position that would suggest some form of causal relationship, we do suggest that the use of a school MIS acts to tighten the coupling with schools, and between schools and central education authorities. This tighter coupling then enables central education authorities to exercise a form of 'control at a distance' over school operations without appearing to intervene directly.

\section{CONCLUSION}

King and Sethi (1999) have argued that the use of information technology is fundamental to effective operation of firms operating globally, as it provides a co-ordinating mechanism for their dispersed activities and also enables coalitions to be established. In a similar way we have argued that the use of school management information systems provides a coordinating mechanism so that central education authorities can keep track of what schools are doing, and also enables coalitions of teachers, principals, school councils/school boards and the central Education Ministry to be established in the administration and managements of schools.

\section{REFERENCES}

Berkhout, S.J. and Wielemans, W. (1999) Toward understanding education policy: An integrative approach. Educational Policy, Los Altos, 13, 3, 402-420

Birse, J. (1994) Schools' Administrative Computing Unit (Victoria). Recorded Interview, Melbourne.

Bottery, M. (1999) Education Under the New Modernisers: An Agenda for Centralisation, Illiberalism and Inequality? Cambridge Journal of Education, 29, 1

Chapman, D.W. (2000) Trends in Educational Administration in Developing Asia. Educational Administration Quarterly, 36, 2, 283-308

Gershberg, A.I. (1999) Education 'decentralisation' processes in Mexico and Nicaragua: Legislative versus ministry-led reform strategies. Comparative Education, 35, 1, 63-80

Glassman, R.B. (1973) Persistence and Loose Coupling in Living Systems. Behavioral Science, 18, 83-98 
King, W.R. and Sethi, V. (1999) An empirical assessment of the organisation of transnational information systems. Journal of Management Information Systems, 15, 4, 7-28

Latour, B. (1993)We have never been modern. Hemel Hempstead: Harvester Wheatsheaf

Latour, B. (1996) Aramis or the Love of Technology. Cambridge, MA: MIT Press

Provincial Committee on Aims and Objectives of Education in the Schools of Ontario (1968) Living and Learning. Toronto: The Newton Publishing Company

Sayed, Y. (1999). Discourses of the policy of educational decentralisation in South Africa since 1994: An examination of the South African Schools Act. Compare, 29, 2, 141-152

Tatnall, A. (1995). Information Technology and the Management of Victorian Schools Providing Flexibility or Enabling Better Central Control? In B.-Z. Barta, M. Telem and Y. Gev. Information Technology in Educational Management. London: IFIP/Chapman Hall

Telem, M. (1998). School Administration Computerisation Impact on the Teacher's Role: A Case Study. Journal of Urban Education, 33, 4, 534-555

Weick, K.E. (1976) Educational Organisations as Loosely Coupled Systems. Administrative Science Quarterly, 21, 1-19

Weick, K.E. (1982) Administering Education in Loosely Coupled School. Phi Delta Kappan, 63, 673-676

\section{BIOGRAPHIES}

Arthur Tatnall is a senior lecturer in the School of Information Systems at Victoria University in Melbourne, Australia. His Ph.D. involved a study in curriculum innovation in which he investigated the manner in which Visual Basic entered the curriculum of an Australian university. His research interests include technological innovation, information systems curriculum, and information technology in educational management. Allan Pitman is an associate professor in the Faculty of Education at the University of Western Ontario, Canada. He has a Ph.D. from the University of Wisconsin. Originally also an Australian, for many years he has been actively involved in educational research, including a project funded by the Ford Foundation and a comparative study in locus of control in teacher education in several countries. 